\section{JURNAL EKONOMI EFEKTIF}

ISSN : $2622-8882$, E-ISSN : 2622-9935

Jurnal Ekonomi Efektif, Vol. 2, No. 4, Juli 2020

@Prodi Manajemen Fakultas Ekonomi Universitas

Pamulang

\title{
PENGARUH KEGIATAN PROMOSI TERHADAP MINAT BELI KONSUMEN PADA PT. SERASI PERKASA DI TANGERANG
}

\author{
Cornelia Dumarya Manik \\ Universitas Pamulang, Tangerang Selatan, Banten, Indonesia \\ *cornelia00720@unpam.ac.id
}

\begin{abstract}
ABSTRAK
Penelitian ini bertujuan untuk mengetahui pengaruh Kegiatan Promosi terhadap Minat Beli Konsumen pada PT. Serasi Perkasa di Tangerang. Metode yang digunakan adalah explanatory research dengan sampel sebanyak 83 responden. Teknik analisis menggunakan analisis statistik dengan pengujian regresi, korelasi, determinasi dan uji hipotesis. Hasil penelitian ini variabel Kegiatan Promosi diperoleh nilai rata-rata skor sebesar 3,502 dengan kriteria baik. Variabel Minat Beli Konsumen diperoleh nilai rata-rata skor sebesar 3,799 dengan kriteria baik. Kegiatan Promosi berpengaruh positif dan signifikan terhadap Minat Beli Konsumen dengan nilai persamaan regresi $\mathrm{Y}=11,3801+0,760 \mathrm{X}$, dan nilai koefisien korelasi 0,747 atau memiliki tingkat hubungan yang kuat dengan nilai determinasi 55,9\%. Uji hipotesis diperoleh signifikansi $0,000<0,05$.
\end{abstract}

Kata Kunci: Kegiatan Promosi, Minat Beli Konsumen.

\section{ABSTRACT}

This study aims to determine the effect of promotional activities on consumer buying interest at PT. Serasi Perkasa in Tangerang. The method used is explanatory research with a sample of 83 respondents. The analysis technique uses statistical analysis with regression testing, correlation, determination and hypothesis testing. The results of this research variable promotional activities obtained an average score of 3.502 with good criteria. The Consumer Purchase Interest variable obtained an average score of 3,799 with good criteria. Promotion activity has a positive and significant effect on Consumer Purchase Interest with the regression equation value $Y=11.3801+0.760 X$, and the correlation coefficient value of 0.747 or has a strong level of relationship with a determination value of 55.9\%. Hypothesis testing obtained a significance of $0.000<0.05$.

Keywords: Promotion Activities, Consumer Purchase Interest. 


\section{PENDAHULUAN}

\section{A. Latar Belakang Masalah}

Pakaian merupakan salah satu kebutuhan pokok sehari-hari konsumen. Untuk memenuhi kebutuhan tersebut konsumen membelinya dari toko-toko terdekat. PT. Serasi Perkasa merupakan agen grosir pakaian yang menjual produk dengan cara online maupun offline yang menjual dalam jumlah besar maupun satuan dengan sistem ini PT. Serasi Perkasa dapat menyuplai pakaian baik didalam maupun diluar wilayah Depok melalui sistem penjulan secara langsung maupun tidak langsung.

Namun kini penjualan melalui media online begitu marak dan perkembangannya begitu pesat sehingga persaingan yang dihadapi PT. Serasi Perkasa sangatlah tajam sehingga diperlukan strategi-strategi yang mampu bersaing. Oleh karena itu pemasaran merupakan salah satu tujuan yang paling penting terhadap penjualan suatu produk. Berhasil atau tidaknya kehidupan suatu perusahaan tergantung dari hasil penjualan yang dilakukan perusahaan tersebut.

Faktor promosi yang dilakukan oleh perusahaan menjadi sangat penting karena pPromosi merupakan suatu bentuk komunikasi pemasaran, dimana komunikasi pemasaran adalah aktivitas pemasaran yang berusaha menyebarkan informasi, mempengaruhi, membujuk mengingatkan pasar atas perusahaan atau produknya agar bersedia menerima, membeli dan loyal pada produk yang ditawarkan, (Fandy Tjiptono, 2007:103).

Setiap usaha atau langkah yang dilakukan perusahaan adalah untuk memuaskan konsumen, perusahaan dituntut untuk melakukan strategi pemasaran yang tepat agar mempunyai suatu produk yang memiliki keunggulan dari pesaingnya dan juga perusahaan harus menyampaikan informasi tentang produk-produknya agar dapat menarik konsumen yang potensial sehingga dapat mempertahankan dan meningkatkan hasil penjualan perusahaan.

Salah satu kegiatan pemasaran yang cukup efektif dan efisien adalah promosi. Menurut Freddy Rangkuti (2012:50), promosi adalah "Kegiatan penjualan dan pemasaran dalam rangka menginformasikan dan mendorong permintaan terhadap produk, jasa dan ide dari perusahaan dengan cara mempengaruhi konsumen agar mau membeli produk dan jasa yang dihasilkan oleh perusahaan".

Promosi merupakan salah satu faktor yang sangat penting, karena promosi dapat mempengaruhi secara langsung terhadap kelancaran maupun keberhasilan perusahaan dalam mencapai tujuannya. Oleh karena itu kelancaran maupun keberhasilan suatu perusahaan sangat tergantung pada manajemen didalam membuat rencana kegiatan promosi yang akan datang, baik jangka pendek maupun jangka panjang.

Dengan adanya promosi yang terencana, maka perusahaan dapat mendekati pembeli atau calon konsumen agar mau membeli produk yang mereka tawarkan. Disamping itu promosi erat kaitannya dengan kelangsungan hidup suatu perusahaan. Promosi yang berhasil sebenarnya tidak hanya mampu meningkatkan hasil penjualan semata-mata, akan tetapi dapat memberikan keuntungan-keuntungan lain seperti nama perusahaan akan dikenal oleh konsumen dan hasil produksinya dapat meningkatkan efisiensi penggunaan modal kerja, memperkecil piutang, dan lain-lain. Dan sebaliknya jika strategi tidak berhasil, maka dapat menyebabkan kenaikan biaya per unit, keuntungan yang diperoleh dalam tiap unit menurun sehingga dengan sendirinya penghasilan perbulan pun menurun.

Masih banyak konsumen yang belum mengetahui secara jelas tentang berbagai macam produk yang dimiliki PT. Serasi Perkasa, untuk itu diharapkan kegiatan-kegiatan promosi yang dilakukan dapat mengenai sasaran dengan tepat, guna memberikan informasi mengenai produk pakaian secara jelas, sehingga konsumen mendapatkan informasi yang dalam mengenai produk pakaian di PT. Serasi Perkasa, promosi dimaksudkan untuk 
menarik minat beli konsumen, antara lain dengan memberikan informasi selengkapnya kepada konsumen akan suatu produk yang dipasarkan. Jika kegiatan promosi terlaksana dengan baik, maka konsumen akan tertarik dan akan membeli produk tersebut. Cara memperkenalkan produk terhadap konsumen dapat mengadakan acara-acara promosi seperti sosialisasi produk, pameran, sharing session produk didaerah-daerah yang lebih luas lagi jangkauannya dan masih banyak lagi acara lainnya yang dapat dilaksanakan guna memperkenalkan produk kepada konsumen.

Diharapkan dengan dilaksanakanya kegiatan promosi, minat beli konsumen akan meningkat, dikarenakan dengan tumbuhnya rasa tertarik konsumen akan produk yang ditawarkan pada acara-acara promosi yang diselengarakan tersebut. Dalam berbagai kegiatan promosi yang dilakukan PT. Serasi Perkasa sebisa mungkin sebagai penyelenggara acara, harus dapat membuat kegiatan promosi menjadi menarik, contohnya dengan membuat acara-acara, dari menentukan tema acara yang unik, penampilan untuk menayangkan informasi produk yang dipromosikan menggunakan design slide yang menarik, sound effect yang berkualitas, sampai dengan pembagian souvenir kepada para pengunjung acara. Diharapkan kegiatan promosi tersebut memiliki daya tarik yang kuat bagi konsumen untuk memutuskan membeli produknya.

Maka dari itu promosi memegang Penting dalam dalam mencapai tujuan perusahaan terutama dalam mendapatkan keuntungan maksimal dengan biaya terkecil. Promosi merupakan kegiatan pokok yang dilakukan pengusaha untuk kelangsungkan hidup perusahaan yang selanjutnya berkembang dan mencapai hasil penjualan yang diinginkan, sehingga dapat diartikan bahwa kepuasan pelanggan merupakan suatu keadaan dimana keinginan dan harapan pelanggan dapat terpenuhi.

Kegiatan promosi dilakukan guna memberikan informasi kepada konsumen yang masih belum mengenal produk secara jelas, didukung dengan penyajian program-program promosi lainnya yang berhubungan dengan produk yang dipasarkan. Hal ini diharapkan dapat menorong minat beli konsumen akan suatu produk, minat beli konsumen diharapkan akan berubah, dari yang sebelumnya tidak berminat untuk membeli menjadi berminat untuk membeli. Effendy (Effendy, 2003:305) mendefinisikan minat sebagai; "Kelanjutan dari perhatian yang merupakan titik tolak bagi timbulnya hasrat (desire) untuk melakukan suatu kegiatan yang diharapkan komunikator". Hal yang kontradiktif justru terjadi di perusahaan diantaranya kegiatan-kegiatan promosi yang dilakukan PT. Serasi Perkasa dalam mempengaruhi minat beli konsumen masih sangat minim, minat beli konsumen cenderung berkurang sehingga mengurangi omzet penjualan.

Hal ini dipengaruhi oleh kegiatan yang dilakukan contohnya menyelenggrakan program sosialisasi produk sebagai ajang memberikan informasi mengenai produk lama yang sudah ada dengan tujuan agar manfaat dari produk dapat digunakan dengan baik dan benar oleh pelanggan, selain itu untuk menarik minat pelanggan PT. Serasi Perkasa juga meyelenggarakan acara- acara untuk memperkenalkan produk barunya. Cara ini dimaksudkan untuk memberikan gambaran terhadap konsumen akan produk, dan agar lebih menarik perhatian pelanggan, penyelenggaraan disarankan dapat menyediakan berbagai macam hadiah yang dapat menarik minat konsumen. Dengan demikian penulis tertarik untuk mengadakan riset lebih lanjut, adapun judul penelitian yang penulis lakukan adalah "Pengaruh Kegiatan Promosi Terhadap Minat Beli Konsumen Pada PT. Serasi Perkasa di Tangerang"

\section{B. Rumusan Masalah}

1. Bagaimana Kegiatan Promosi pada PT. Serasi Perkasa di Tangerang ?.

2. Bagaimana Minat Beli Konsumen pada PT. Serasi Perkasa di Tangerang ?. 
3. Adakah pengaruh antara Kegiatan Promosi terhadap Minat Beli Konsumen pada PT. Serasi Perkasa di Tangerang?.

\section{Tujuan Penelitian}

1. Untuk mengetahui kondisi Kegiatan Promosi pada PT. Serasi Perkasa di Tangerang.

2. Untuk mengetahui kondisi Minat Beli Konsumen pada PT. Serasi Perkasa di Tangerang.

3. Untuk mengetahui pengaruh antara Kegiatan Promosi terhadap Minat Beli Konsumen pada PT. Serasi Perkasa di Tangerang.

\section{TINJAUAN PUSTAKA}

\section{Kegiatan Promosi}

Menuurut Kotler dan Keller (2017:263) berpendapat "Promosi merupakan ramuan khusus dari iklan pribadi, promosi penjualan dan hubungan masyarakat yang digunakan perusahaan untuk mencapai tujuan iklan dan pemasarannya". Sedangkan Babin (2017:26) "Promosi merupakan fungsi komunikasi dari perusahaan yang bertanggung jawab menginformasikan dan membujuk/mengajak pembeli”. Lain halnya dengan Tjiptono (2017:229) "Promosi penjualan adalah bentuk persuasi langsung melalui penggunaan berbagai insentif yang dapat diatur untuk merangsang pembelian produk dengan segera dan meningkatkan jumlah barang yang dibeli pelanggan".

\section{Minat Beli Konsumen}

Menurut Mowen (2017:24) berpendapat "Minat beli adalah sesuatu diperoleh dari proses belajar dan proses pemikiran yang yang membentuk suatu persepsi". Minat beli ini menciptakan suatu motivasi yang terus terekam dalam benaknya dan menjadi suatu keinginan yang sangat kuat yang pada akhirnya ketika seorang konsumen harus memenuhi kebutuhannya akan mengaktualisasikan apa yang ada didalam benaknya itu. Sedangkan menurut Kinnear dan Taylor (2011:26), "Minat beli merupakan bagian dari komponen perilaku konsumen dalam sikap mengkonsumsi, kecenderungan responden untuk bertindak sebelum keputusan membeli benar-benar dilaksanakan”.

\section{METODE PENELITIAN}

1. Populasi

Populasi dalam penelitian ini berjumlah 83 responden PT. Serasi Perkasa di Tangerang

\section{Sampel}

Teknik pengambilan sampling dalam penelitian ini adalah sampel jenuh, dimana semua anggota populasi dijadikan sebagai sampel. Dengan demikian sampel dalam penelitian ini sampel yang digunakan berjumlah 83 responden.

\section{Jenis Penelitian}

Jenis penelitian yang dipakai adalah asosiatif, dimana tujuannya adalah untuk mengetahui atau mencari keterhubungan antara variabel independen terhadap variabel dependennya

\section{Metode Analisis Data}

Dalam menganalisis data digunakan uji validitas, uji reliabilitas, analisis regresi linier sederhana, analisis koefisien korelasi, analisis koefisien determinasi dan pengujian hipotesis.

\section{HASIL PENELITIAN}




\section{Analisis Deskriptif}

Pada pengujian ini digunakan untuk mengetahui skor minimum dan maksimum skor tertinggi, ratting score dan standar deviasi dari masing-masing variabel. Adapun hasilnya sebagai berikut:

Tabel 1. Hasil Analisis Descriptive Statistics

\begin{tabular}{l|r|r|r|r|r}
\multicolumn{7}{c}{ Descriptive Statistics } \\
& N & Minimum & Maximum & Mean & Std. Deviation \\
\hline Kegiatan Promosi (X) & 83 & 30 & 48 & 35.02 & 3.895 \\
\hline Minat Beli Konsumen $(\mathrm{Y})$ & 83 & 32 & 49 & 37.99 & 3.959 \\
\hline Valid N (listwise) & 83 & & & & \\
\hline
\end{tabular}

Kegiatan Promosi diperoleh varians minimum sebesar 30 dan varians maximum 48 dengan ratting score sebesar 3,502 dengan standar deviasi 3,895. Skor ini termasuk pada rentang sakala 3,40-4,19 dengan kriteria baik atau setuju.

Minat Beli Konsumen diperoleh varians minimum sebesar 32 dan varians maximum 49 dengan ratting score sebesar 3,799 dengan standar deviasi 3,968. Skor ini termasuk pada rentang sakala 3,40 - 4,19 dengan kriteria baik atau setuju.

\section{Analisis Verifikatif.}

Pada analisis ini dimaksudkan untuk mengetahui pengaruh variabel independen terhadap variabel dependen. Adapun hasil pengujian sebagai berikut:

\section{a. Analisis Regresi Linier Sederhana}

Uji regresi ini dimaksudkan untuk mengetahui perubahan variabel dependen jika variabel independen mengalami perubahan. Adapun hasil pengujiannya sebagai berikut:

Tabel 2. Hasil Pengujian Regresi Linier Sederhana

\begin{tabular}{lr|r|r|r|r} 
& \multicolumn{2}{c}{ Coefficients $^{\mathbf{a}}$} \\
& \multicolumn{2}{c}{$\begin{array}{l}\text { Unstandardized } \\
\text { Coefficients }\end{array}$} & $\begin{array}{c}\text { Standardized } \\
\text { Coefficients }\end{array}$ & & \\
Model & \multicolumn{1}{c}{ B } & Std. Error & Beta & \multicolumn{1}{c}{ t } & \multicolumn{1}{c}{ Sig. } \\
\hline 1 (Constant) & 11.380 & 2.643 & & 4.305 & .000 \\
\hline Kegiatan Promosi (X) & .760 & .075 & .747 & 10.127 & .000 \\
\hline
\end{tabular}

Berdasarkan hasil pengujian pada tabel di atas, diperoleh persamaan regresi $\mathrm{Y}=$ 11,3801 + 0,760X. Dari persamaan tersebut dijelaskan sebagai berikut:

1) Konstanta sebesar 11,3801 diartikan jika Kegiatan Promosi tidak ada, maka telah terdapat nilai Minat Beli Konsumen sebesar 11,3801 point.

2) Koefisien regresi Kegiatan Promosi sebesar 0,760, angka ini positif artinya setiap ada peningkatan Kegiatan Promosi sebesar 0,760 point maka Minat Beli Konsumen juga akan mengalami peningkatan sebesar 0,760 point.

\section{b. Analisis Koefisien Korelasi}

Analisis koefisien korelasi dimaksudkan untuk mengetahui tingkat kekuatan hubungan dari variabel independen terhadap variabel dependen. Adapun hasil pengujian sebagai berikut:

Tabel 3. Hasil Pengujian Koefisien Korelasi Kegiatan Promosi Terhadap Minat Beli Konsumen.

\section{Correlations $^{b}$}

\begin{tabular}{c|c} 
Kegiatan & Minat Beli \\
Promosi $(\mathrm{X} 1)$ & Konsumen $(\mathrm{Y})$ \\
\hline
\end{tabular}




\begin{tabular}{llrr}
\hline Kegiatan Promosi (X) & Pearson Correlation & 1 & $.747^{\star *}$ \\
\cline { 2 - 4 } & Sig. (2-tailed) & .000 \\
\hline Minat Beli Konsumen (Y) & Pearson Correlation & $.747^{* *}$ & 1 \\
\cline { 2 - 4 } & Sig. (2-tailed) & .000 & \\
\hline
\end{tabular}

Berdasarkan hasil pengujian diperoleh nilai korelasi sebesar 0,747 artinya Kegiatan Promosi memiliki hubungan yang kuat terhadap Minat Beli Konsumen.

\section{c. Analisis Koefisien Determinasi}

Analisis koefisien determinasi dimaksudkan untuk mengetahui besarnya persentase pengaruh dari variabel independen terhadap variabel dependen. Adapun hasil pengujian sebagai berikut:

Tabel 4. Hasil Pengujian Koefisien Determinasi Kegiatan Promosi Terhadap Minat Beli Konsumen.

\begin{tabular}{|c|c|c|c|c|}
\hline \multicolumn{5}{|c|}{ Model Summary } \\
\hline Model & $\mathrm{R}$ & R Square & $\begin{array}{l}\text { Adjusted R } \\
\text { Square }\end{array}$ & $\begin{array}{l}\text { Std. Error of the } \\
\text { Estimate }\end{array}$ \\
\hline 1 & $.747^{a}$ & .559 & .553 & 2.646 \\
\hline
\end{tabular}

Berdasarkan hasil pengujian diperoleh nilai determinasi sebesar 0,559 artinya Kegiatan Promosi memiliki kontribusi pengaruh sebesar 55,9\% terhadap Minat Beli Konsumen, sedangkan sisanya sebesar $44,1 \%$ dipengaruhi oleh faktor lain yang tidak dilakukan penelitian.

\section{d. Uji Hipotesis}

Pengujian hipotesis dengan uji t digunakan untuk mengetahui hipotesis mana yang diterima.

Rumusan hipotesis: Terdapat pengaruh yang signifikan antara Kegiatan Promosi terhadap Minat Beli Konsumen.

Tabel 5. Hasil Uji Hipotesis Kegiatan Promosi Terhadap Minat Beli Konsumen.

\begin{tabular}{|c|c|c|c|c|c|}
\hline \multirow[b]{2}{*}{ Model } & $\begin{array}{r}\text { Co } \\
\text { Unst } \\
\text { Co }\end{array}$ & $\begin{array}{l}\text { ficients }^{a} \\
\text { idardized } \\
\text { ficients }\end{array}$ & \multirow{2}{*}{$\begin{array}{c}\text { Standardized } \\
\text { Coefficients } \\
\text { Beta }\end{array}$} & \multirow[b]{2}{*}{$\mathrm{t}$} & \multirow[b]{2}{*}{ Sig. } \\
\hline & B & Std. Error & & & \\
\hline 1 (Constant) & 11.380 & 2.643 & & 4.305 & .000 \\
\hline Kegiatan Promosi (X) & .760 & .075 & .747 & 10.127 & .000 \\
\hline
\end{tabular}

Berdasarkan hasil pengujian pada tabel di atas, diperoleh nilai t hitung $>\mathrm{t}$ tabel atau $(10,127>1,990)$, dengan demikian hipotesis yang diajukan bahwa terdapat pengaruh yang signifikan atara Kegiatan Promosi terhadap Minat Beli Konsumen diterima.

\section{Pembahasan Hasil Penelitian}

\section{Kondisi Jawaban Responden Variabel Kegiatan Promosi}

Berdasarkan jawaban responden, variabel Kegiatan Promosi diperoleh ratting score sebesar 3,502 berada di rentang skala 3,40 - 4,19 dengan kriteria baik atau setuju.

\section{Kondisi Jawaban Responden Variabel Minat Beli Konsumen}

Berdasarkan jawaban responden, variabel Minat Beli Konsumen diperoleh ratting score sebesar 3,799 berada di rentang skala 3,40-4,19 dengan kriteria baik atau setuju. 


\section{Pengaruh Kegiatan Promosi Terhadap Minat Beli Konsumen}

Kegiatan Promosi berpengaruh signifikan terhadap Minat Beli Konsumen dengan persamaan regresi $\mathrm{Y}=11,3801+0,760 \mathrm{X}$, nilai korelasi sebesar 0,747 atau memiliki hubungan yang kuat dengan kontribusi pengaruh sebesar 55,9\%. Pengujian hipotesis diperoleh nilai $t$ hitung $>\mathrm{t}$ tabel atau $(10,127>1,990)$. Dengan demikian hipotesis yang diajukan bahwa terdapat berpengaruh signifikan antara Kegiatan Promosi terhadap Minat Beli Konsumen diterima.

\section{KESIMPULAN DAN SARAN}

1. Kesimpulan

a. Variabel Kegiatan Promosi diperoleh ratting score sebesar 3,502 berada di rentang skala 3,40 - 4,19 dengan kriteria baik atau setuju.

b. Variabel Minat Beli Konsumen diperoleh ratting score sebesar 3,799 berada di rentang skala 3,40-4,19 dengan kriteria baik atau setuju.

c. Kegiatan Promosi berpengaruh signifikan terhadap Minat Beli Konsumen dengan persamaan regresi $\mathrm{Y}=11,3801+0,760 \mathrm{X}$, nilai korelasi sebesar 0,747 atau kuat dan kontribusi pengaruh sebesar $55,9 \%$ sedangkan sisanya sebesar $44,1 \%$ dipengaruhi faktor lain. Uji hipotesis diperoleh nilai $\mathrm{t}$ hitung $>\mathrm{t}$ tabel atau $(10,127>1,990)$.

\section{Saran}

a. Kegiatan Promosi PT. Serasi Perkasa harus lebih diperhatikan dan ditingkatkan lagi, terutama dalam hal tingkat manfaat kupon yang diberikan dan Tingkat pemberian Barang Iklan yang masih belum terlalu disukai oleh Pelanggan, untuk itu PT. Serasi Perkasa harus segera mengganti atau mengadakan perbaikan, dan jangan terlalu dibiarkan terlalu lama.

b. Minat beli Konsumen harus lebih ditumbuhkan dan ditingkatkan kembali, karena tingkat keinginan menggunakan produk serta tingkat pengaruh kualitas masih rendah maka harus dapat segera diselesaikan agar tujuan yang dicapai 518act dapat tercapai atau bahkan 518act melewati target yang diinginkan.

c. Kegiatan Promosi merupakan salah satu 518actor yang sangat mempengaruhi minat beli Konsumen, sebaiknya kegiatan promosi tersebut dapat dimaksimalkan agar minat beli konsumen dapat meningkat sehingga visi, misi dan tujuan PT. Serasi Perkasa dapat tercapai.

\section{DAFTAR PUSTAKA}

Abdullah, M (2014) Manajemen dan Evaluasi Minat Beli Konsumen, Yogyakarta: Penerbit Aswaja Pressindo.

Algifari. (2015). “Analisis Regresi untuk Bisnis dan Ekonomi”. Yogyakarta: BPFE.

AR. Bulaeng, "Komunikasi Pemasaran”, Pusat Penerbit Universitas Terbuka, Jakarta, 2002.

Arikunto, Suharsimi (2014). "Prosedur Penelitian Suatu Pendekatan Praktek". Jakarta:

Rineka Cipta.

Assael, "Customer Behavior and Marketing Action", Four Edition, Kent Publishing, New York, 2002.

Bashu Swastha dan T. Handoko (2015) Manajemen Pemasaran Moderen, Yogyakarta: BPFE.

Bilson Simamora (2016) Panduan Riset Prilaku Konsumen, Jakarta: PT. Gramedia Pustaka. Effendi, Onong Uchjana," Hubungan Masyarakat Suatu Studi Komunikologis", PT. Remaja 
Rosdakarya, Bandung, 2003.

Erlangga, H. (2019, August). The Spirit Of The Development Of Entrepreneurship In Higher Education. In International Conference of One Asia Community (Vol. 1, No. 1, pp. 38-48).

Fandy Tjiptono (2017), Serivce Quality and Satisfiation. Jakarta: Edisi tiga. Andi.

Freddy Rangkuti (2016) Strategi Promosi Yang Kreatif, Edisi Pertama, Cetakan Pertama Jakarta: Gramedia Pustaka Utama.

Imam Ghozali (2017). “Aplikasi Analisis Multivariate Dengan Program SPSS”. Edisi Kelima. Semarang: Badan Penerbit Undip.

Ilham, D. (2019). Implementing Local Wisdom Values in Bride and Groom Course at KUA Bara SubDistrict, Palopo City. Jurnal Konsepsi, 8(1), 1-9.

Ilham, D. (2019). Menggagas Pendidikan Nilai dalam Sistem Pendidikan

Nasional. Didaktika: Jurnal Kependidikan, 8(3), 109-122.

Jasmani, J. (2018). Pengaruh Kualitas Produk Dan Harga Terhadap Keputusan Pembelian Pada PT. Baja Mandiri Di Jakarta. Disrupsi Binis, 1(1).

Jasmani, J. (2019). Pengaruh Promosi Dan Pengembangan Produk Terhadap Peningkatan Hasil Penjualan. Jurnal Semarak, 1(3).

Kasmir, "Etika Customer Service", Raja Grafindo Persada, Jakarta, 2004.

Kharis, Ismu Fadli (2011). "Studi Mengenai Impulse Buying dalam Penjualan Online". Semarang : Skripsi Universitas Diponegoro

Kotler dan Amstrong (2017), Prinsip-prinsip Pemasaran. Edisi Kedua Belas”. Jilid Satu. Jakarta: Erlangga.

Lupiyoadi (2016) Manajemen Pemasaran Jasa, Edisi 4, Jakarta: Salemba Empat.

Lupiyoadi, "Manajemen Pemasaran Jasa”, Salemba Empat, Jakarta, 2008.

Luthans Fred (2014) Organizational Behavior, Ney York: McGraw-Hill, New York.

Muhibbib Syah, "Psikologi Belajar”, PT. Raja Grafindo Persada, Jakarta, 2003.

Muis, I., Nurdin, I., Erlangga, H., \& Engkus, E. (2019). Post Disaster Social Vulnerability: Policy Analysis and Implementation in Communities in Indonesia. Journal of Critical Reviews, 6(5), 59-66.

Mulyana, Deddy, “Metodologi Penelitian Kuantitatif”, PT. Raja Grafindo Persada, Jakarta, 2003.

Philip Kotler (2017) Manajemen Pemasaran, Edisi Keempat Belas, Jakarta: PT. Indeks.

Phipil Kotler dan Kevin Keller (2017) Manajemen Pemasaran, Edisi Kedua Belas, Jilid Satu, Jakarta: Erlangga.

Riduwan, "Metode dan Tehnik Penyusunan Proposal Penelitian", Pustaka Presindo, Jakarta, 2012.

Saladin, Djaslim, ”Manajemen Pemasaran”, Linda Karya, Bandung, 2003.

Santoso, Singgih (2015). “Menguasai Statistik Multivariat”. Jakarta: PT Elex Media Komputindo.

Sudjana (2014) “Metode Statistika”, Bandung: Tarsido.

Sugiyono (2017), "Metode Penelitian Administrasi : dilengkapi dengan Metode $R \& D$ ”. Bandung: Alfabeta.

Suhartanto (2014). “Metode Riset Pemasaran”. Bandung: Alfabeta

Sunarsi, D., \& Baharuddin, A. (2019). The Effect of Service Quality and Price Accuracy on Consumer Confidence and Implications for Sales Increase. PINISI Discretion Review, 3(2), 101-110.

Wiliam J. Shultz, “Marketing”, Prentice Hall Inc, Zulganef, New York, 2001.

Wiliam J. Stanton, "Prinsip Pemasaran”, Jilid Satu, Edisi Kesepuluh, Erlangga, Jakarta, 2002. 